\title{
ESTIMATING STORM DIRECT RUNOFF USING SYNTHETIC UNIT HYDROGRAPH METHODS BY (WMS) MODEL (SOLAG BASIN AS A CASE STUDY)
}

\author{
KHALID M. KHIDIR ${ }^{*}$ and MOHANAD T. AL-SHA'AR ${ }^{* *}$ \\ *Dept .of Water Resources Engineering, University of Duhok, Kurdistan Region-Iraq \\ ** Dept. of Dams and Water Resources Engineering, University of Mosul-Iraq
}

\begin{abstract}
The Storm Runoff Volume and its Peak are important for designing and operating dams and different hydraulic structures.

Watershed Modeling System (WMS) version (8.1) and The HEC-1 v (4.1) hydrological models were used in this study to estimate the Synthetic runoff hydrograph resulting from two storm events over Solag Basin which is located in Sinjar District north of Iraq, making use of available recorded storms rainfall and Synthetic unit hydrograph technique. Direct runoff hydrographs are determined using Natural Resources Conservation Service (NRCS), Snyder Synthetic Unit Hydrograph and Clark methods.

Nash model was used to compare the efficiency of the Synthetic runoff Hydrograph using both Synthetic and recorded discharge data for Solag basin which were available for two storms within water years 19911992. Synthetic unit hydrographs are important in flood studies and water resources management.
\end{abstract}

KEYWORDS: Solag, Basin, WMS, Synthetics, Hydrograph, Runoff.

\section{INTRODICTION}

W atershed Modeling System (WMS) is a comprehensive hydrologic modeling system that provides tools for all phases of basin modeling including automated basin, geometric parameter computation and hydrologic parameter computation $(\mathrm{CN}$, time of concentration, rainfall depth, etc.).

The derivation of the direct runoff hydrographs resulting from certain rainfall storms over the basin is necessary to avoid flood as well as for operating and designing different water resources projects.

A unit hydrograph (UH) represents runoff hydrograph produced from one unit depth of rainfall excess uniformly distributed over the entire basin falling at a uniform rate for a specified duration.

In cases, of recorded runoff data which required to derive a unit hydrograph and then the runoff Hydrographs, the synthetic unit hydrograph can be used to estimate runoff hydrographs for the ungagged basin. Different methods can be used to evaluate synthetic unit hydrograph, but in this study three methods were adopted and compared using statistical test to get the most efficient one. These methods are Snyder unit hydrograph,
Dimensionless unit hydrograph (NRCS) and Clark method unit hydrograph.

Khidir (1999) presented a deterministic conceptual - non liner mathematical method for the simulation of the hydrological processes and estimation of surface runoff resulting from rainfall storms for basins in north of Iraq. The model was applied for two sets of basins in different locations, one of them was Solag basin. He used different statistical tests to check the conformance between estimated hydrograph and the recorded for different storms.

Ali and AL Thamiry (2011) conducted a study on Goizha-Dabashan basin located in the north east of Iraq, in AL-Sulymaniah city. In their study they estimated the runoff volume and peak runoff with aid of WMS software and using HEC-1 model. Two techniques were used to evaluate the runoff, Rational method and Natural Resource Conservation Service (NRCS) method. Results indicated that the NRCS is better than Rational for evaluating the peak runoff.

Abdulrahman (2010) developed and applied different methods of Instantaneous unit hydrograph model for Solag basin. In this study estimation the excess rainfall for storms was done using Phi index ( $\Phi$ index) and Natural Resource Conservation Service (NRCS) methods. 
Yannopoulos et. al. (2005) compared the analyzed the Snyder synthetic unit hydrograph, Natural Resources Conservation Service (NRCS) and Clark using WMS program and HEC-1 model for portaicos river basin in Greece. Results indicated that the NRCS is the better one.

Younis et. al. (2014) conducted a study on khazir river basin, north of Iraq. In this research WMS model applied to assess the capability of two methods, which were Natural Resource Conservation Service (NRCS) and Mockus model for estimating runoff hydrograph. The results showed that the peak discharges estimated by 2 . HEC-1 model using WMS software was mostly closest to the recorded one.

Melching and Marquardt (1997) established a relations correlated between basic hydrograph parameters of basin and rainfall storm characteristics, which can be used for estimating synthetic unit hydrographs for small ungagged basins in Lake County Illinois.

There are different basins in Iraq, where they are unrecorded and very important locations, so it is necessary to get a synthetic hydrological data for them.

The purpose of this study is to estimate the synthetic runoff hydrograph for Solag basin using three different methods.

\section{. STUDY AREA}

The study area was Solag basin located in the north west of Iraq, in Sinjar District as shown in Figure (1).

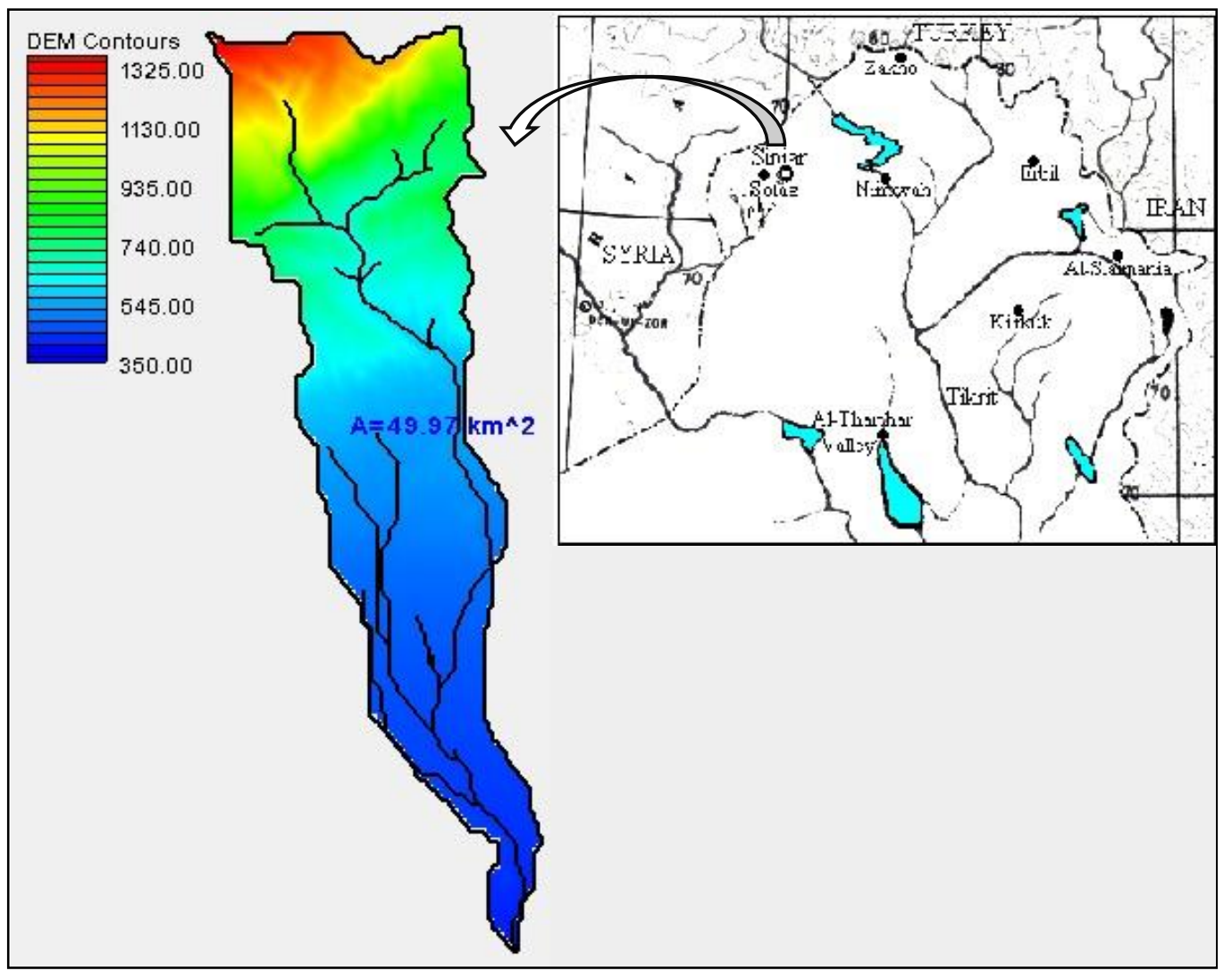

Fig. (1): Map of the northern Iraq showing the basin under study

Solag basin was delineated from DEM (digital elevation model) with resolution $30 \mathrm{~m}$ with the aid of WMS. The basin parameters like basin slop, max stream length, centroid stream distance, basin area, and etc. were computed from the DEM with the help of WMS software after delineating the basin boundary.
The outlet of the basin is located at $41^{\circ} 58^{\prime} 12^{\prime \prime}$ $\mathrm{E}$ (Longitude) and $36^{\circ} 14^{\prime} 24^{\prime \prime} \mathrm{N}$ (Latitude). The basin area is $\left(50 \mathrm{~km}^{2}\right)$, the perimeter is $(54.57$ $\mathrm{km})$, the mean basin elevation is $(636 \mathrm{~m})$, the basin slope is $(0.1016 \mathrm{~m} / \mathrm{m})$, and the maximum flow distance is $(22.83 \mathrm{~km})$ as got from the application of (WMS) software for the basin. characteristics. 
The rainfall records and runoff data were available for two rainfall storms for the water years 1991, 1992 (Khidir, 1999).

The information about land uses and soil types which were needed to estimate the value of curve number $(\mathrm{CN})$ are estimated using Satellite image from Landsat-8 (17/5/2014) and then with aid Erdas software land use map has been developed for Solag basin shown Figure (2). The Soil type map was got of from the state establishment of geological survey and mining (geological map of Sinjar quadrangle, sheet NJ-37-16) Figure (3).
From features of WMS program, it provides possible means to evaluate the average weighted curve number $(\mathrm{CN})$ for any basin with availability of the maps for land use and soil type. The Solag basin has been divided into many polygons, each polygon represents land use description in land use map or describe the hydrologic soil group in soil type map. With aid of (WMS) software land use and soil type maps were conformed to obtain unified map in order to find the average weight $(\mathrm{CN})$ which was equal to 77.2.

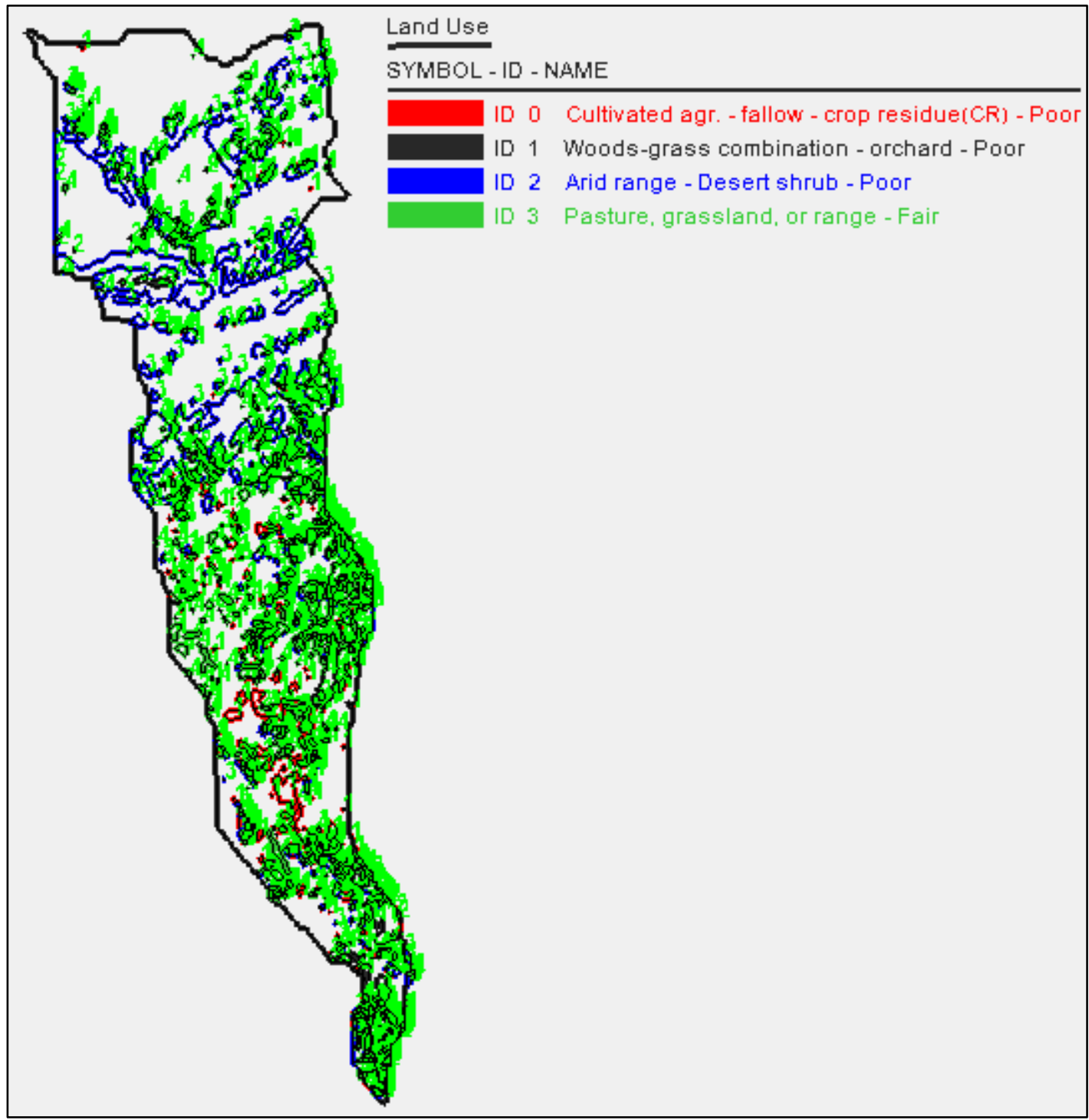

Fig. (2): Land Use Map for Solag Basin Using WMS Software. 


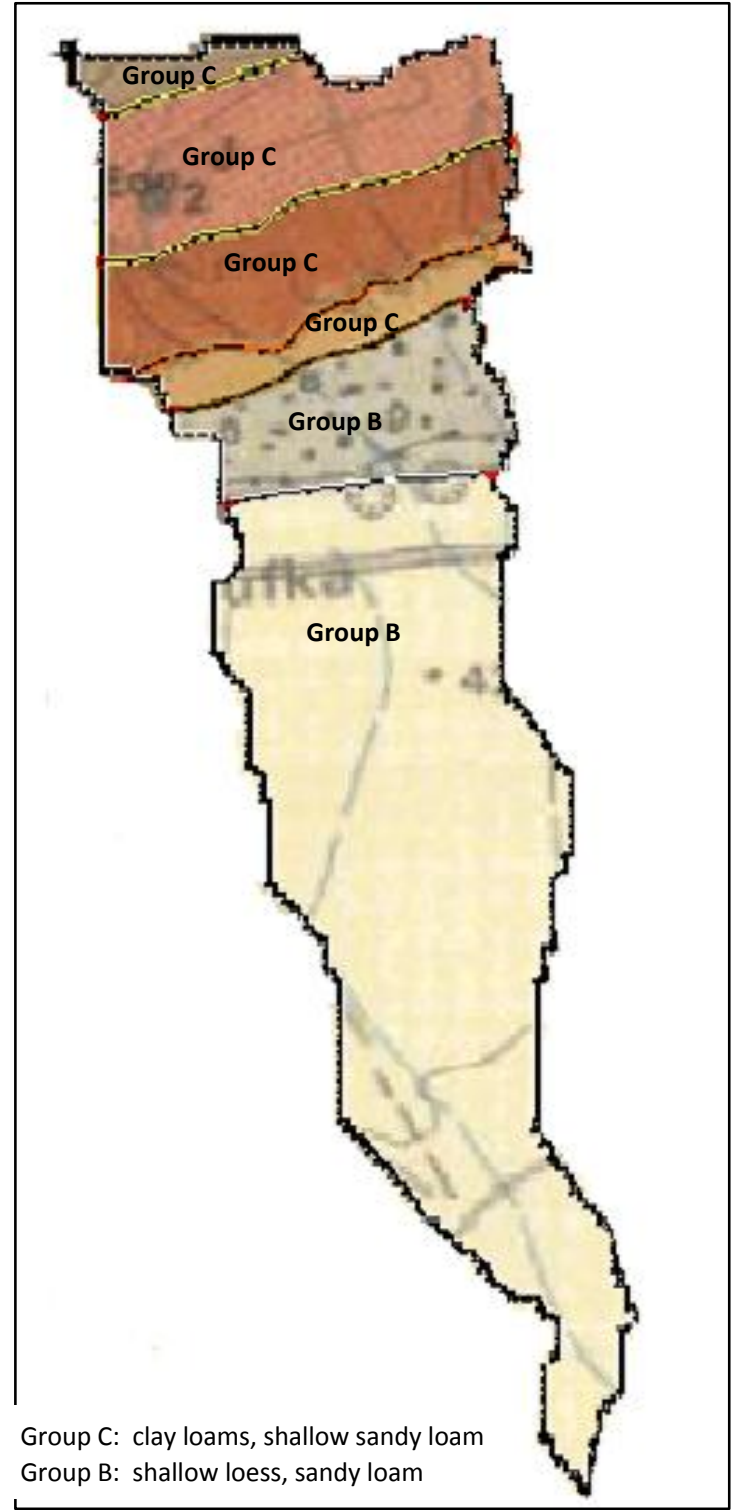

Fig. (3): Soil Type Map for Solag Basin Using WMS Software.

\section{HYDROLOGICAL SIMULATION (HEC-1)} MODEL

The HEC-1 is a hydrological model (Hydrologic Engineering Center, U.S.A), supported by the Watershed Modeling System software (WMS) v 8.1 and it's preferred because the equations of model are known.

The hydrological model (HEC-1) uses a set of synthetic unit hydrograph methods, such as NRCS dimensionless unit hydrograph, Clark unit hydrograph and Snyder unit hydrograph. These methods have been used in this study to simulate and estimate the runoff hydrograph for two rainfall recorded storms in the water years 1991, 1992 over the Solag basin.
The computation of rainfall loss rate in HEC-1 model is an important parameter and supported by WMS loss methods. The initial loss was found by WMS software using $\mathrm{CN}$ method.

\section{THEORITICAL BACKGROUND OF THE SURFACE RUNOFF HYDROGRAPH}

Rainfall distribution represents the first phase of HEC-1 hydrological model in WMS software to identify the rainfall as hyetograph. The Natural Resources Conservation Service (NRCS) method was used in the present study for the computation of the excess rainfall, which was used to estimate the synthetic unit hydrograph by different methods, these methods are: 


\section{a) Clark's method}

Clark established (Walega, et. al. 2011) a method for deriving unit hydrograph for the basin depending on the relation between time and area of the basin. Clark method is based on the theory that conversion of flow through the basin can be described by surface runoff isochrones and the corresponding histogram of contributing area against time as shown in Figure (4).

The time of concentration (Tc) in the Clark unit hydrograph is the time from the end of excess rainfall to the second inflection point which lies on the recession limb of the surface runoff hydrograph. Kirpich equation has been used to compute the time of concentration which takes the form (Chow, 1988):

$\mathrm{Tc}=0.00013 \mathrm{~L}^{0.77} \mathrm{~S}^{-0.385}$

Where:

Tc: Time of concentration, (hr).

L: Length of channel from the farthest point to the outlet of the basin, $(\mathrm{km})$.

S: Slope of the longest hydraulic length.

The storage coefficient (R) and time of concentration $(\mathrm{Tc})$ are the hydrograph parameters requisite in HEC-1 model with WMS software to calculate the Clark unit hydrograph. The value of (R) is calculated by WMS software after computing $(\mathrm{Tc})$, where the Clark's $(\mathrm{R})=\mathrm{R}$ coeff. * Tc

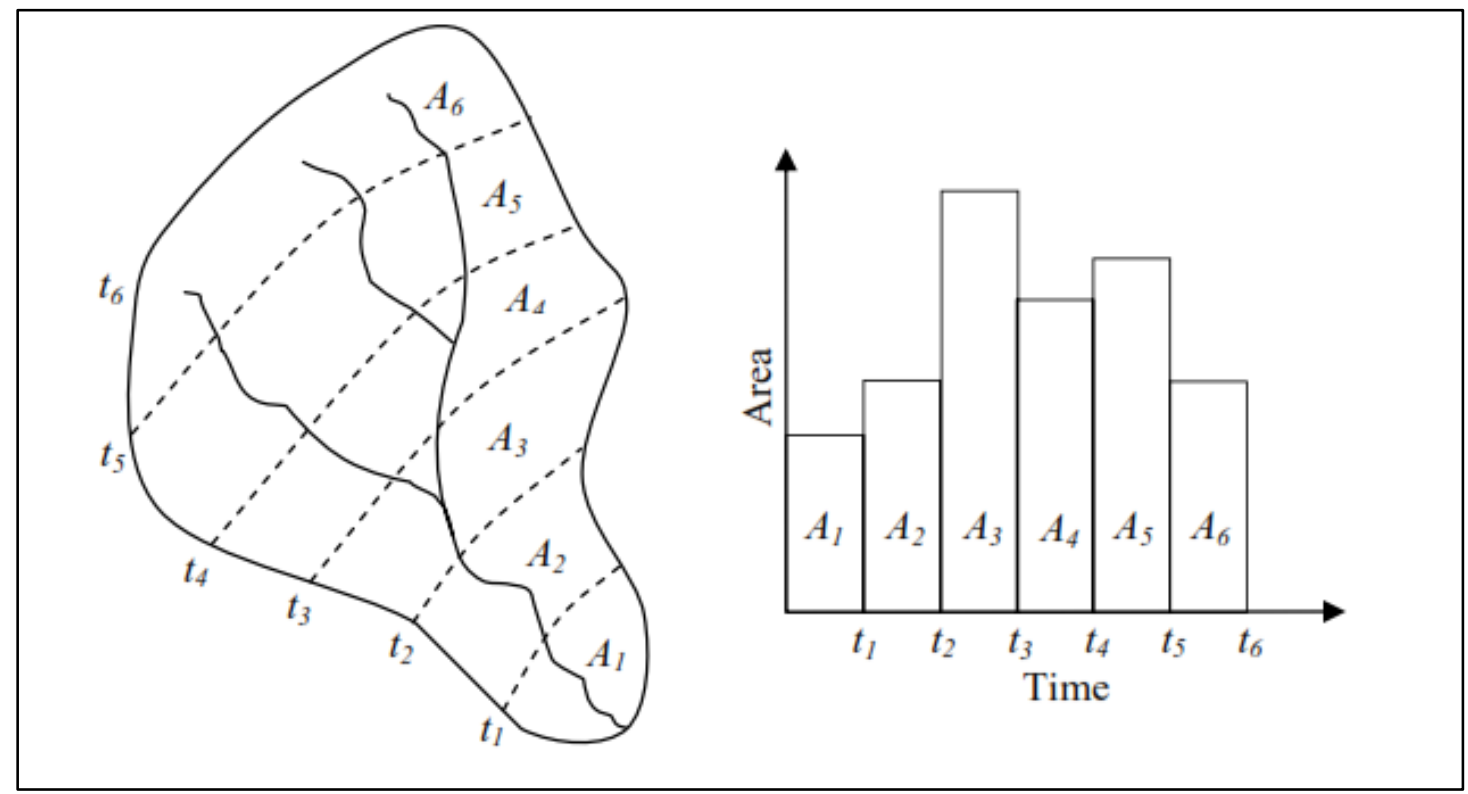

Fig. (4): Time-area isochrones and histogram for Clark's method (www.innovyze.com/book).

\section{b) Snyder method}

Snyder developed (Subramanya, 2005) a group of empirical equations for estimating synthetic unit hydrographs which correlate the features of a standard unit hydrograph and main characteristics of the basin. The essential parameter of a basin affecting a hydrograph is lag time. The lag time in Snyder unit hydrograph $\left(t_{\mathrm{L}}\right)$ is the time interval from the centroid of excess rainfall to the hydrograph peak. Lag time is calculated by the relation

$\mathrm{t}_{\mathrm{L}}=\mathrm{C}_{\mathrm{t}}\left[\mathrm{L} \mathrm{L} \mathrm{La}_{\mathrm{ca}} / \sqrt{S}\right]^{\mathrm{n}}$

Where:

$\mathrm{t}_{\mathrm{L}}$ : Lag time, (hr).

$\mathrm{C}_{\mathrm{t}}, \mathrm{n}$ : The basin constants.

L: Length of basin, (km).

$\mathrm{L}_{\mathrm{ca}}$ : Length to basin centroid, $(\mathrm{km})$.
S: Maximum flow distance slope.

The peak discharge $Q_{P}\left(\mathrm{~m}^{3} / \mathrm{s}\right)$, time to peak $t_{p}$ (hr) and time to base $t_{b}(h r)$ of a unit hydrograph by Snyder method can be estimated using the relations.

$\mathrm{Q}_{\mathrm{P}}=2.78 \mathrm{C}_{\mathrm{P}} \mathrm{A} / \mathrm{t}_{\mathrm{L}}$

$\mathrm{t}_{\mathrm{p}}=\mathrm{t}_{\mathrm{L}}+0.5 \mathrm{t}_{\mathrm{d}}$

$\mathrm{t}_{\mathrm{b}}=72+3 \mathrm{t}_{\mathrm{L}}$

Where:

$\mathrm{C}_{\mathrm{P}}$ : Regional constant.

A: Area of basin in $\left(\mathrm{km}^{2}\right)$.

$t_{d}$ : Duration of rainfall excess, (hr).

$\mathrm{W}_{75}$ and $\mathrm{W}_{50}$ represent the width of unit hydrograph in time units (hr) at discharge values exceeded $75 \%$ and $50 \%$ of the peak discharge respectively, which are computed by:

$\mathrm{W}_{50}=5.37 / \mathrm{q}^{1.08}$ 
$\mathrm{W}_{75}=\mathrm{W}_{50} / 1.75$

Where:

q: Unit peak discharge, $\left(\mathrm{m}^{3} / \mathrm{sec} / \mathrm{km}^{2}\right)$.
These and other different relations are used by Snyder method to estimate the synthetic UH, of a general shape shown in Figure

(5).

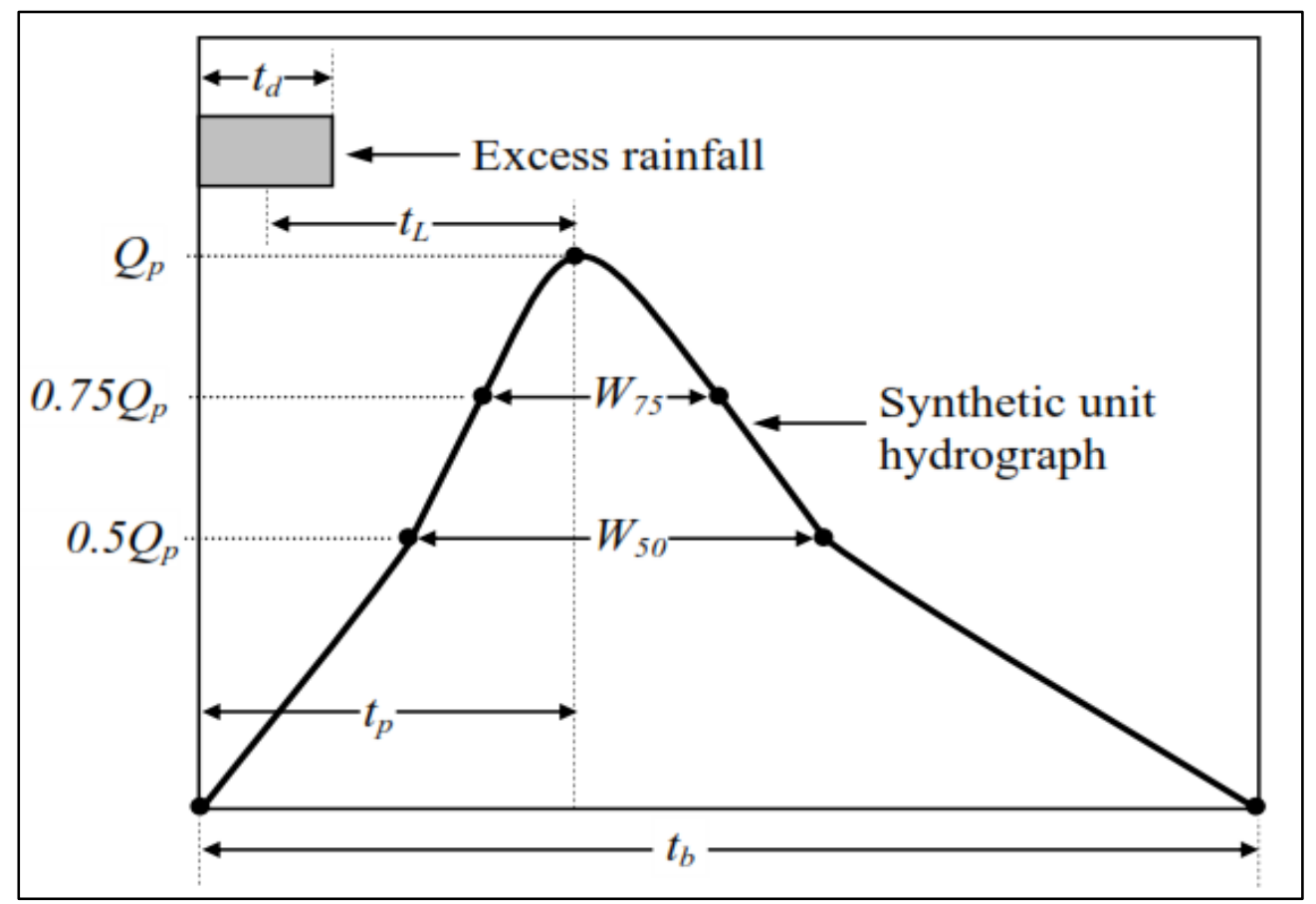

Fig. (5): Shape of Synthetic Unit hydrograph by Snyder's method (www.innovyze.com/book).

\section{c) NRCS dimensionless method}

NRCS method (Ven Te Chow, 1988) is one of the famous synthetic unit hydrograph methods. In this method the discharge $(\mathrm{Q})$ is expressed by the ratio of discharge $(\mathrm{Q})$ to the peak discharge $\left(\mathrm{Q}_{\mathrm{p}}\right)$ and the time by ratio of $(\mathrm{t})$ to the time to peak $\left(\mathrm{t}_{\mathrm{p}}\right)$. Figure (6-a) and (6-b) show both dimensionless and triangular $\mathrm{UH}$ which were estimated by this method. The time of concentration (Tc) in (NRCS) is the time interval from the end of excess rainfall to the inflection point on the recession limb. The relationship between (Tc) and the basin lag $\left(t_{L}\right)$ Time to peak $\left(t_{p}\right)$ can be estimated by the following equation:

$\mathrm{t}_{\mathrm{L}}=0.6 \mathrm{~T}_{\mathrm{c}}$

Peak discharge $\left(\mathrm{Q}_{\mathrm{p}}\right)$ can be estimated by applying the empirical equation:
$\mathrm{Q}_{\mathrm{p}}=\mathrm{CA} / \mathrm{t}_{\mathrm{p}}$

Where:

C: Discharge Coefficient. It is 2.08 in SI system and 484 in English system

A: Area of basin, $\left(\mathrm{km}^{2}\right)$.

The above methods are applied for the basin under study through using the (WMS) software with the available recorded data of two storms for the basin to estimate the synthetic runoff hydrograph.

The synthetic unit hydrograph converted to runoff hydrograph by applying the HEC-1 model in WMS software. The procedure of conversion is explained in hydrology books (Ven Te Chow, 1988, Subramanya K, 2005). 


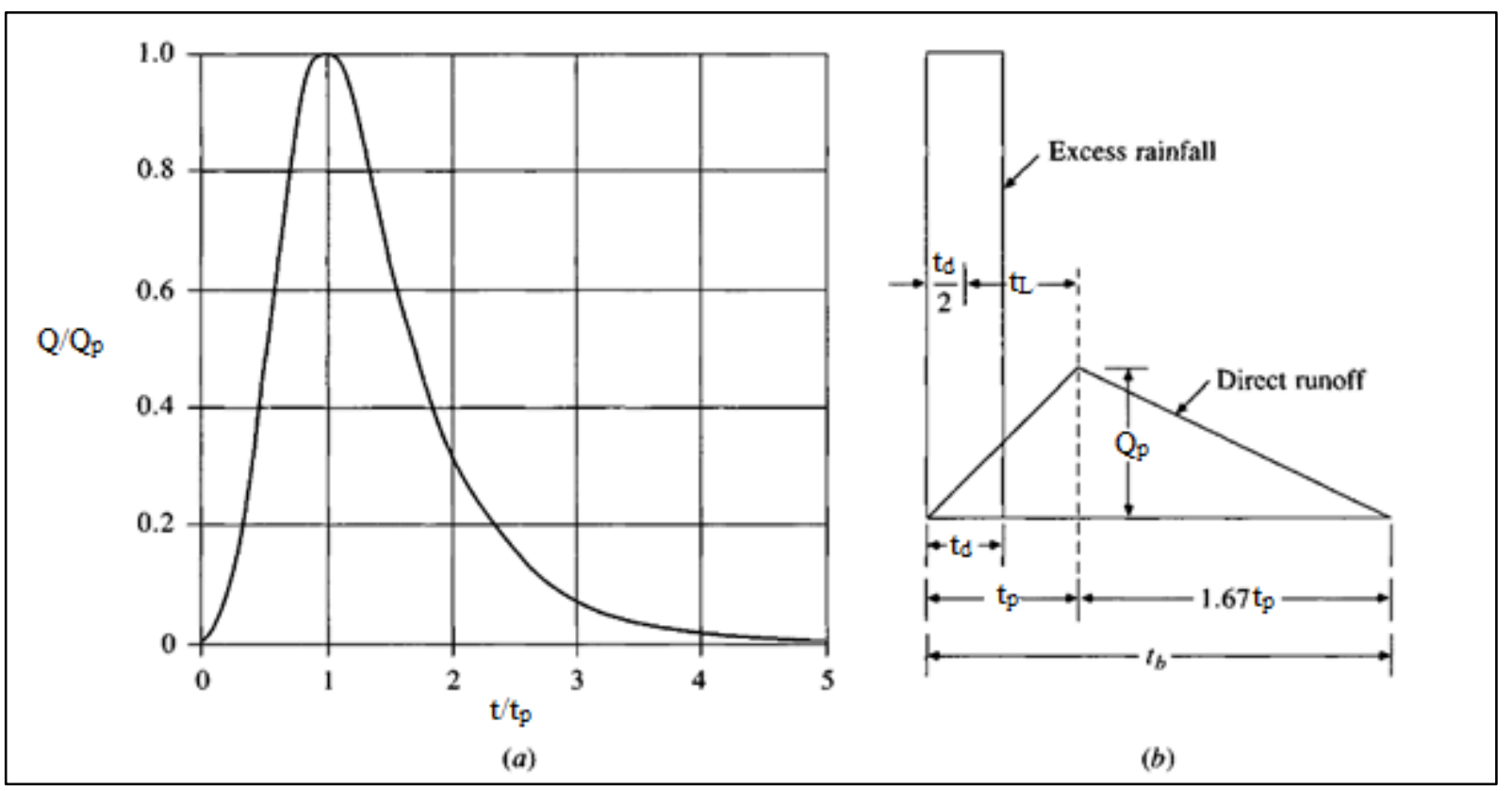

Fig. (6): (a) dimensionless Unit hydrograph (b) Triangular Unit hydrograph for NRCS method (Ven Te Chow,

\section{STATISTICAL TEST}

Nash model of estimating the efficiency was used to test the capability of the different methods by comparing the synthetic and recorded discharges for mentioned storms. Nash efficiency model takes the form:

$\mathrm{E}=1-\Sigma\left(\mathrm{Qc}_{\mathrm{t}}-\mathrm{Qr}_{\mathrm{t}}\right)^{2} / \Sigma\left(\mathrm{Qr}_{\mathrm{t}}-\mathrm{Q} \mathrm{r}_{\mathrm{t}}\right)^{2}$

Where:

$\mathrm{E}=$ Nash model Efficiency.

$\mathrm{Qr}_{\mathrm{t}}$ : Recorded discharge value at the time $\mathrm{t}$, $\left(\mathrm{m}^{3} / \mathrm{sec}\right)$.

Q $\mathrm{r}_{\mathrm{i}}$ : Mean of recorded values at the time $\mathrm{t}$, $\left(\mathrm{m}^{3} / \mathrm{sec}\right)$.

$\mathrm{Qc}_{\mathrm{t}}$ : The Synthetic discharge values at the time $\mathrm{t}$, $\left(\mathrm{m}^{3} / \mathrm{sec}\right)$.

\section{RESULTS AND DISCUSSION}

The simulation results of synthetic runoff hydrograph of Solag basin for the storms under study are shown in figures (7) and (8) respectively, which shown also the recorded runoff hydrographs for the same storms.

The total runoff volume, peak runoff and time to peak for storm are estimated and tabulated in Table (1) and (2) respectively. These two tables show that the total runoff volume by Snyder method is the nearest one to the recorded runoff for the two storms. Also table (1) shows that the synthetic peak runoff value for storm (1) by 1988)

Snyder method is the nearest one to the recorded. But for storm (2) NRCS method gave the nearest peak synthetic value to the recorded peak. Table (3) shows the efficiency values of Nash model for Clark, NRCS and Snyder methods. High efficiency value of Nash model for Snyder method indicates that this method was the better one, and this can be seen from its direct runoff hydrograph which is the more one approach to the recorded runoff hydrograph.

\section{CONCLUSION}

Synthetic direct runoff hydrograph for the storms can be estimated more accurately for ungagged basins by applying different synthetic unit hydrograph techniques, like Snyder, NRCS and Clark and choosing the best one according to the statistical test result, as done in this study by applying WMS software which facilitated applying these techniques. Two recorded storms for Solag basin in Sinjar district in north of Iraq were used in this study to check the capability of WMS model. In the time that NRCS and Snyder gave a highest values for Nash efficiency test but this test shows also that Snyder method is the best one, where the resulted synthetic hydrograph coincided closer with the recorded one, so this method can be recommended to be used for estimating synthetic DRH for the available recorded rainfall storms for Solag basin within Sinjar

distract. 


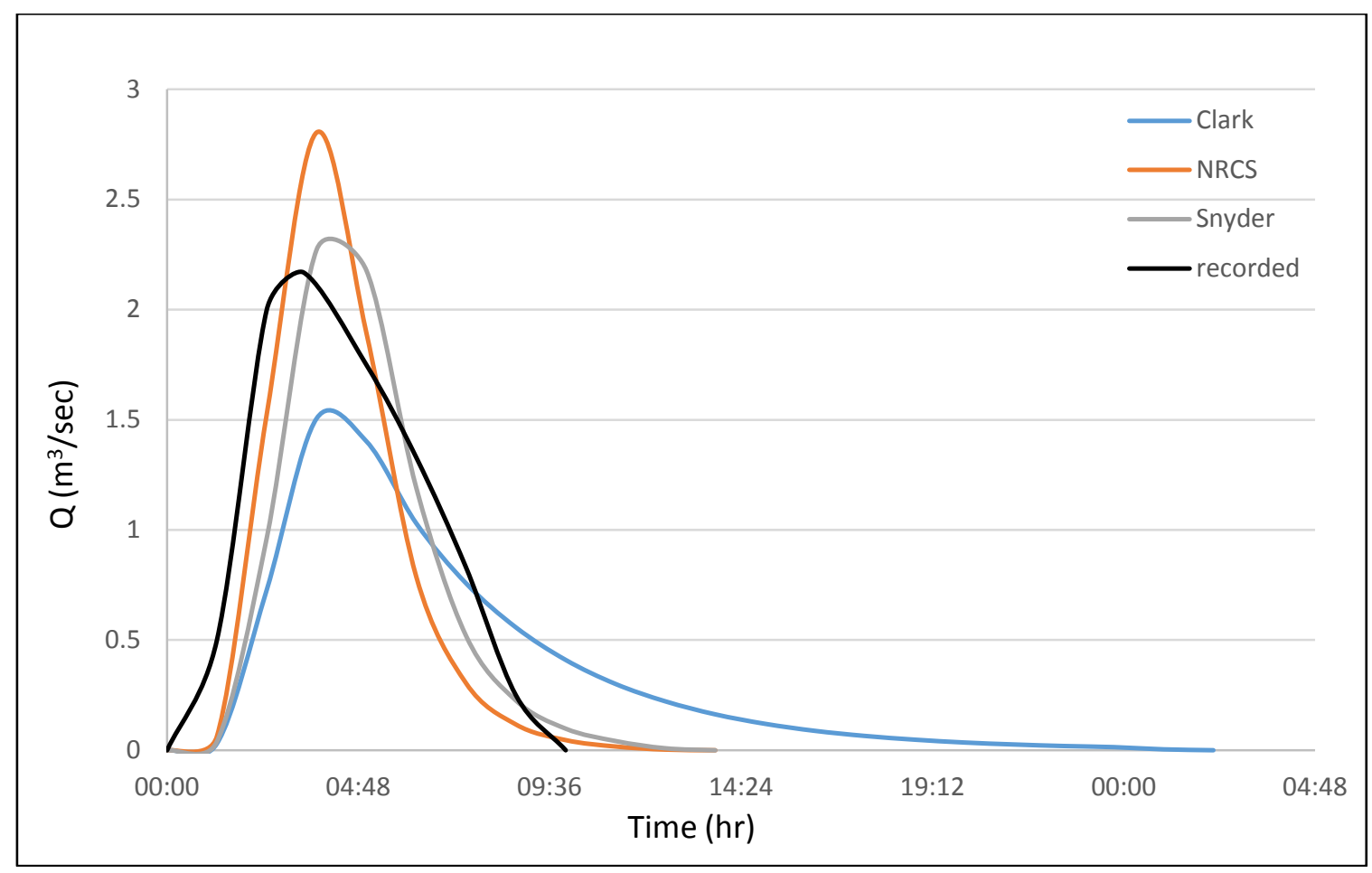

Fig. (7): Recorded and Synthetic runoff hydrographs using Clark, NRCS and Snyder methods for storm No. (1) As estimated by application of WMS model.

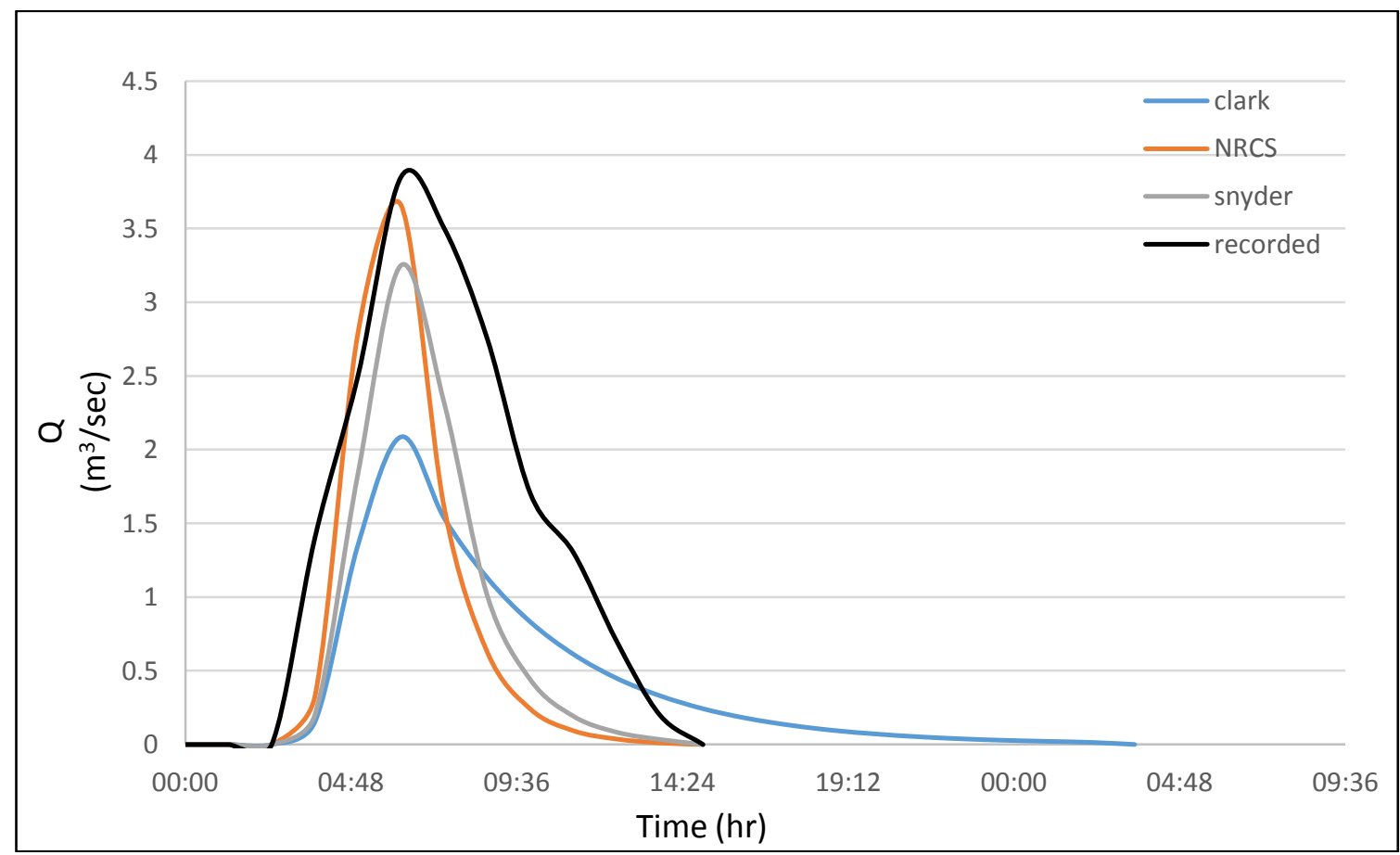

Fig.(8): Recorded and Synthetic runoff hydrographs by using Clark, NRCS and Snyder methods for storm No. (2) As estimated by application of WMS model 
Table (1): Values of Peak runoff (Qp), Peak time (Tp) and total runoff (V) for the recorded and the synthetic runoff hydrograph by Clark, NRCS and Snyder, for storm (1)

\begin{tabular}{ccccc}
\hline \multicolumn{2}{c}{$\begin{array}{c}\text { Hydrograph } \\
\text { Storm 1 }\end{array}$} & $\begin{array}{c}\text { Peak runoff, } \\
\left(\mathbf{m}^{\mathbf{3}} / \mathbf{s e c}\right)\end{array}$ & $\begin{array}{c}\text { Peak time, } \\
(\mathbf{h r s})\end{array}$ & $\begin{array}{c}\text { Total runoff volume } \\
\mathbf{V}\left(\mathbf{m}^{\mathbf{3}}\right)\end{array}$ \\
\hline Recorded & & 2.17 & 3.42 & $47,407.5$ \\
\hline \multirow{3}{*}{ Computed } & Clark & 1.51 & 3.75 & $33,880.5$ \\
\cline { 2 - 5 } & NRCS & 2.8 & 3.75 & 34,029 \\
\cline { 2 - 5 } & Snyder & 2.27 & 3.75 & $33,925.5$ \\
\hline
\end{tabular}

Table (2): Values of Peak runoff (Qp), Peak time (Tp) and total runoff (V) for the recorded and the synthetic runoff hydrograph by Clark, NRCS and Snyder, for storm (2).

\begin{tabular}{ccccc}
\hline \multicolumn{2}{c}{$\begin{array}{c}\text { Hydrograph } \\
\text { Storm 2 }\end{array}$} & $\begin{array}{c}\text { Peak runoff, } \mathbf{Q}_{\mathbf{p}} \\
\left(\mathbf{m}^{3} / \mathbf{s e c}\right)\end{array}$ & $\begin{array}{c}\text { Peak time, } \\
(\mathbf{h r s})\end{array}$ & $\begin{array}{c}\text { Total runoff volume } \\
\mathbf{V}\left(\mathbf{m}^{3}\right)\end{array}$ \\
\hline Recorded & 3.85 & 6.25 & 76,950 \\
\hline Computed & Clark & 2.09 & 6.25 & $42,043.5$ \\
\cline { 2 - 5 } & NRCS & 3.66 & 6.25 & $42,232.5$ \\
\cline { 2 - 5 } & Snyder & 3.25 & 6.25 & 42,102 \\
\hline
\end{tabular}

Table (3): Values of Nash Efficiency for the two storms.

\begin{tabular}{cccc}
\hline & \multicolumn{3}{c}{ Synthetic technique } \\
\cline { 2 - 4 } Storm & Clark & NRCS & Snyder \\
\hline $\mathbf{1}$ & 0.728 & 0.870 & 0.873 \\
\hline $\mathbf{2}$ & 0.555 & 0.573 & 0.710 \\
\hline
\end{tabular}

\section{REFERENCES}

- Ali, A. M., and Thamiry, H. A. (2011). Estimation of Runoff for Goizha - Dabashan Basin Aid of Remote Sensing Techniques. Journal of Engineering, Number 2, Volume 17, pp. 306320.

- Chow, V. T., Maidment, D. R., and Mays, L. W. (1988). Applied Hydrology , New York: McGraw - Hill.

- Haji Ali, E. A. (2010). Application of Different Models for Development of Instantaneous Unit Hydrograph for Solag Basin. A Thesis (M.Sc.) in Water Resources Engineering, University of Duhok, College of Engineering.

- HEC-1 (1998). Flood Hydrograph Package HEC - 1: $\mathrm{v}$ 4.1. User's Manual. U.S.A: Hydrologic Engineering Center, United States Army Corps of Engineering.

- Innovating for Sustainable Infrastructure. Chapter Five. Surface Runoff, from www.innovyze.com/book store/.

- Khidir, Kh. M. (1999). Determination of Mathematical Model for Estimation Surface Runoff for Some Basins Northern Iraq. A Thesis (Ph.D.) in Water Resources Engineering, College of Engineering, University of Mosul.

- McCuen, R. H. (1998). Hydrologic Analysis and Design (2nd ed.). Bill Stenquist.

- Melching, C. S., and Marquardt, J. S. (1997). Equations for Estimating Synthetic Unit Hydrograph Parameter Values for Small
Watersheds in Lake County, Illinois. U.S. Geological Survey, Prepared in cooperation with Lake County Storm Water Management Commission.

- Natural Resources Conservation Service (2010). National Engineering Handbook. United States Department of Agriculture.

- Subramanya, K. (2005). Engineering Hydrology (2nd ed.). Tata: McGraw-Hill.

- Walega, A., Paluszkiewicz, B., and Grzebinoga, M. (2011). On Using The Snyder and Clark Unit Hydrograph for Calculations of Flood Waves in a Highland Catchment (The Grabinka River Example). Acta Scientiarum polonorum, Formation Circumiectus, 47-56.

- WMS (2004). Watershed Modeling System v 8.1: Tutorials. Environmental Modeling Research Laboratory of Brigham Young University, Utah. U.S.

- Yannopoulos S., Katsi, A. and Papamichail, D. (2005). Rainfall - Runoff Process Simulation using the Watershed Modeling System (WMS) software. Proceedings of $6^{\text {th }}$ International Conference of European Water Resources Association, Menton, France: pp. 111-122.

- Younis, A. M., Hasan, I. F., and Saeed, Y. N. (2014). Comparison Study of Two Methods Used to Estimate Surface Runoff Hydrograph for Small Basins. Journal of Engineering and Development, Vol. 18, No.6, November 2014, ISSN 1813-7822. 